\title{
THIRTY YEARS OF TROPICAL CYCLONE RESEARCH WITH THE NOAA P-3 AIRCRAFT
}

by Sim D. Aberson, Michael L. Black, Robert A. Black, Robert W. Burpee, Joseph J. Cione, Christopher W. Landsea, and Frank D. Marks Jr.

\section{This year marks the 30th anniversary of the acquisition and use of the} two NOAA P-3 aircraft for hurricane research and operations.

$\mathrm{T}$ ropical cyclones (TCs) have been observed by both reconnaissance and research aircraft since the first flight piloted by U.S. Army Air Force Lieutenant Colonel Joseph P. Duckworth on 17 July 1943 (Sumner 1943). The U.S. military conducted the first dedicated research flight into a TC (Wexler 1945; Wood 1945), and a subsequent flight examined the upper troposphere of a 1947 Atlantic TC (Simpson 1954). In the early 1950s, somewhat regular TC research was conducted during operational military reconnaissance flights originating in Bermuda and Guam (Simpson 1952, 2003).

AfFiliations: ABERSON, BLACK, BLACK, CIONE, LANDSEA, AND MARKS - NOAA/AOML/Hurricane Research Division, Miami, Florida; BURPEE-Cooperative Institute for Marine and Atmospheric Studies, University of Miami, Miami, Florida CORRESPONDING AUTHOR: Sim D. Aberson, NOAA/AOML/ Hurricane Research Division, 430 I Rickenbacker Causeway, Miami, FL 33149

E-mail: sim.aberson@noaa.gov

The abstract for this article can be found in this issue, following the table of contents.

DOI:10.1175/BAMS-87-8-1039

In final form 13 April 2006

C2006 American Meteorological Society
Strong Hurricanes Carol, Edna, and Hazel in 1954 killed nearly 200 people and devastated large areas of the Middle Atlantic states, New England, and southern Ontario, Canada (Davis 1954). These disasters, and Hurricanes Carol and Diane in 1955, prompted Congress to allocate money to the Weather Bureau the following year to form the National Hurricane Research Project (NHRP; a short history of NHRP and its successor entities is available online at www. aoml.noaa.gov/hrd/hrd_sub/beginning.html). In August 1956, meteorologists at NHRP began what would become an annual TC research flight program (Simpson 1981; Gentry 1981). ${ }^{1}$ The capabilities of airborne meteorological instrumentation, data recorders, and data processors were limited, so the information gathered during the first flight was not available for analysis for several months. During the first 20 years of the research program, NHRP and two subsequent $\mathrm{TC}$ research laboratories used aircraft whose scientific instrumentation capabilities gradually improved (Gentry 1981).

In the mid-1970s, the National Oceanic and Atmospheric Administration (NOAA) purchased two customized WP-3D (P-3) aircraft. Projected purposes

\footnotetext{
${ }^{1}$ Davies (2000a,b) provides a good description of the mechanics and logistics of the field program.
} 
of the P-3s were observation of TC structure and dynamics, participation in TC modification experiments, and monitoring of TC formation, all with the goal of improving TC forecasts and mitigating damage and loss of life; the P-3s were also to engage in the research of other vital meteorological and oceanographic programs. The NOAA Research Flight Center (now the Aircraft Operations Center) received the first P-3 in 1976 and the other in 1977. Since then, NOAA has maintained the P-3s to be among the premier meteorological research aircraft in the world.

When the P-3s were procured, basic understanding of TC structure and behavior had been deduced from previous research and reconnaissance flights, as well as from other conventional data sources such as rawinsondes and land-based conventional radar. The TC was then considered to be an approximately circular, axisymmetric vortex with nearly constant wind speeds extending to at least $400 \mathrm{hPa}$, and with deviations from axisymmetry considered to be gusts. The eyewall was thought to be vertically aligned up to $5-10 \mathrm{~km}$ above the surface and funnel-shaped above. The eye was observed to have warm, moist air below an inversion, with clear, dry air above and ice clouds streaming inward near the top. Both the eyewall and rainbands were understood to have convergent airflow in low levels and outflow above. Rainbands were seen to move inward toward the eye and to cause intensification of eyewall convection. Numerical modeling of TCs was limited to idealized two-dimensional studies due to a lack of adequate computer power and observations of the dynamic and thermodynamic fields in three dimensions and primitive techniques to assimilate the data into model initial conditions (Simpson and Riehl 1981).

Partially as a result of observations from the P-3s, the description and understanding of TC behavior and structure has been revolutionized. The National Hurricane Research Laboratory and its successor, the Hurricane Research Division (HRD), in collaboration with other governmental, university, and international partners, conducted missions in 134 TCs in the Atlantic and eastern Pacific Oceans and near Australia (Table 1). Data were obtained on the micro- to synoptic scale, and data analyses have led to many new insights about TC structure, dynamics, thermodynamics, and environmental interactions. A brief description of the instrumentation aboard the aircraft is provided in the next section. The real-time use of the data obtained by these instruments during the first 30 years of P-3 flight operations, and resultant research, helped to increase understanding of TC motion (discussed in the section titled "Motion"), intensity (see the section titled "Wind"), and convection (see the section titled "Vertical Motions and Rainfall"), and to improve track, intensity, and rainfall forecasts. A summary is provided in the last section.

INSTRUMENTATION. Sophisticated instrumentation installed on and developed for the P-3s is unique among meteorological airborne platforms. The P-3 is a modified version of a U.S. Navy maritime reconnaissance aircraft that, in turn, is a version of the civilian Lockheed Electra. At delivery, each P-3 was outfitted with a wide variety of tools to observe the TC and its environment (Jorgensen 1984a). The most advanced meteorological equipment on the P-3s consisted of three digital radars that are still used. Two record the reflectivity signal: a $5.5-\mathrm{cm}$-wavelength [lower fuselage (LF)] radar extends below the fuselage and measures the horizontal distribution at all azimuth angles; a 3-cm-wavelength radar is in the tail (TA) and determines the reflectivity distribution along rays oriented either perpendicular to the aircraft track or at angles fore and aft within $25^{\circ}$ of the aircraft heading. A third radar with a $3.1-\mathrm{cm}$ wavelength is in the nose and scans horizontally back and forth; the pilots use it to avoid turbulent weather, and the data have not been recorded since 1987. Important additions to the radar systems first occurred in 1980 when a prototype Doppler signal processing system was added to the TA radar on one P-3 (Jorgensen et al. 1983) and again in 1988-89 when refined radar data systems were installed on both aircraft.

Both P-3s measured flight-level temperature, pressure, and moisture and had a then-state-of-the-art inertial navigation system allowing for flight-level wind speed calculations with $0.1-0.3 \mathrm{~m} \mathrm{~s}^{-1}$ accuracy. Additionally, both P-3s had 24 chutes in the fuselage for external ejection of airborne expendable bathythermographs (AXBTs) to measure ocean temperature to a depth of $\sim 300 \mathrm{~m}$. The P-3s also were equipped with Particle Measuring System probes mounted on the wingtips to distinguish between water and ice particles and estimate particle size (Black and Hallett 1986; Gayet et al. 1993; Baumgardner and Korolev 1997).

The aircraft had three main data systems: one for navigational and flight-level meteorological data, one for radar data, and a third for cloud microphysics data. Observations were recorded on magnetic tapes, a capability that greatly aided timely data processing and analysis.

As electronic equipment and expendable probes became more accurate, smaller, faster, and lighter, new instrumentation enhanced the potential to 
TABLE I. List of TCs investigated by, and number of missions of, each NOAA P-3 (42 and 43) during the first 30 years of dual-aircraft operations. Australian TCs are in boldface font and east Pacific TCs are in italic font.

\begin{tabular}{|c|c|c|c|c|c|c|c|c|c|c|c|}
\hline Year & Storm & 42 & 43 & Year & Storm & 42 & 43 & Year & Storm & 42 & 43 \\
\hline 1976 & Bonny & I & & 1987 & Floyd & 2 & 3 & 1998 & Bonnie & 6 & 5 \\
\hline 1976 & Frances & I & & 1987 & TDI4 & 2 & & 1998 & Danielle & 2 & 2 \\
\hline 1976 & Gloria & 3 & & 1988 & Chris & 3 & 2 & 1998 & Earl & & I \\
\hline 1977 & Anita & 4 & I & 1988 & Florence & 2 & 2 & 1998 & Georges & 7 & 6 \\
\hline 1977 & Heather & I & & 1988 & Gilbert & 8 & 5 & 1998 & Mitch & & 2 \\
\hline 1978 & Debra & & I & 1988 & Joan & & I & 1999 & Bret & 1 & 2 \\
\hline 1978 & Ella & 1 & 3 & 1988 & Keith & & I & 1999 & Dennis & 4 & 3 \\
\hline 1978 & Greta & & 2 & 1989 & Dean & I & 1 & 1999 & Floyd & 4 & 4 \\
\hline 1979 & Kerry & 4 & & 1989 & Gabrielle & 2 & 2 & 1999 & TDII & & 2 \\
\hline 1979 & Rosa & 2 & & 1989 & Hugo & I & 6 & 1999 & Irene & & 2 \\
\hline 1979 & David & 4 & 5 & 1989 & Jerry & & 3 & 1999 & Lenny & & 2 \\
\hline 1979 & Frederic & 4 & 3 & 1990 & Gustav & 4 & 5 & 2000 & Debby & I & \\
\hline 1980 & Allen & 5 & 4 & 1990 & TDII & I & 2 & 2000 & Gordon & I & \\
\hline 1980 & Georges & & I & 1990 & Marco & I & I & 2000 & Helene & & 3 \\
\hline 1981 & Dennis & 2 & 2 & 1991 & Bob & & 2 & 2000 & Keith & I & I \\
\hline 1981 & Floyd & I & I & 1991 & Claudette & I & 2 & 2000 & Leslie & I & 2 \\
\hline 1981 & Gert & 3 & 3 & 1991 & Fabian & I & I & 2000 & Michael & 1 & \\
\hline 1981 & Irene & 2 & 2 & 1991 & Fefa & 2 & & 2001 & Barry & I & \\
\hline 1981 & Katrina & I & 2 & 1991 & Guillermo & 3 & & 2001 & Chantal & I & \\
\hline 1982 & Alberto & & I & 1991 & Jimena & I & 2 & 2001 & Erin & 1 & \\
\hline 1982 & Debby & 3 & 2 & 1992 & Andrew & I & I & 2001 & Gabrielle & 2 & \\
\hline 1982 & Olivia & 2 & 2 & 1992 & Tina & 5 & 3 & 2001 & Humberto & 3 & 2 \\
\hline 1983 & Alicia & 3 & 2 & 1993 & Emily & 4 & 5 & 2001 & Iris & I & \\
\hline 1983 & Barry & I & I & 1994 & Chris & I & 3 & 2001 & Michelle & 3 & \\
\hline 1983 & Dean & I & I & 1994 & Debby & 3 & 2 & 2002 & Edouard & I & I \\
\hline 1983 & Raymond & I & I & 1994 & Olivia & 3 & 3 & 2002 & Gustav & 2 & \\
\hline 1983 & Tico & I & I & 1994 & Gordon & & 2 & 2002 & Hanna & I & I \\
\hline 1984 & Arthur & 3 & & 1995 & Erin & & I & 2002 & Isidore & 5 & 6 \\
\hline 1984 & Diana & 5 & 6 & 1995 & Felix & & 2 & 2002 & Lili & 2 & 5 \\
\hline 1984 & Norbert & 3 & 3 & 1995 & Jerry & I & & 2003 & Claudette & I & \\
\hline 1984 & Isidore & 4 & 4 & 1995 & Iris & 3 & 3 & 2003 & Fabian & 4 & 4 \\
\hline 1984 & Josephine & 3 & 4 & 1995 & Luis & 2 & 2 & 2003 & Isabel & 5 & 3 \\
\hline 1985 & Bob & I & & 1995 & Marilyn & I & & 2004 & Frances & & 6 \\
\hline 1985 & Danny & I & 2 & 1995 & Opal & & I & 2004 & Ivan & 4 & 5 \\
\hline 1985 & Elena & 4 & 7 & 1996 & Bertha & & I & 2004 & Jeanne & 3 & 3 \\
\hline 1985 & Isabel & 3 & 3 & 1996 & Dolly & 3 & 4 & 2005 & Arlene & & I \\
\hline 1985 & Gloria & 4 & 5 & 1996 & Edouard & 4 & 5 & 2005 & Cindy & 1 & \\
\hline 1985 & Juan & I & 3 & 1996 & Fran & I & 1 & 2005 & Dennis & 2 & 4 \\
\hline 1986 & Bonnie & I & & 1996 & Hortense & I & I & 2005 & Emily & & I \\
\hline 1986 & Charley & 2 & I & 1996 & Josephine & I & & 2005 & Gert & 1 & 3 \\
\hline 1986 & Earl & 2 & 2 & 1996 & Lili & 4 & & 2005 & Katrina & & 4 \\
\hline 1986 & Newton & 1 & 1 & 1996 & Marco & & I & 2005 & Ophelia & 8 & 5 \\
\hline 1986 & Paine & 2 & 2 & 1997 & Danny & & I & 2005 & Rita & 2 & 5 \\
\hline 1987 & Arlene & & I & 1997 & Guillermo & 4 & 4 & 2005 & Wilma & 3 & \\
\hline 1987 & Emily & 2 & 3 & 1997 & Erika & & 4 & & & & \\
\hline
\end{tabular}


gather comprehensive TC research datasets. For example, P-3 instruments now include the airborne infrared radiation thermometer (AIRT) for remotely determining flight-level temperature in clear air (Barnes et al. 1991), a stepped frequency microwave radiometer (SFMR) for estimating surface wind speed (Uhlhorn and Black 2003), and Global Positioning System (GPS) navigation. Omega dropwindsondes (ODWs; Govind 1975) were used first in 1982, primarily to study the TC environment. The GPS dropwindsonde (Hock and Franklin 1999), first used in 1996, provided reliable wind and thermodynamic profiles in the TC eyewall for the first time. Each aircraft also carries a workstation for airborne data processing and can now transmit crucial data via satellite to the Global Telecommunications System (Griffin et al. 1992). All of this makes the two P-3s the most advanced and comprehensive of all meteorological research aircraft currently in use.

MOTION. As a TC approaches land, successful evacuations and damage mitigation measures, based on accurate forecasts, can reduce property damage and loss of lives. In 1982, TC numerical modeling was in its infancy, and the best track guidance available to forecasters was statistical. However, to help provide improved synoptic analyses and numerical forecasts to optimize warning areas and increase warning lead times, HRD began to test the hypothesis that additional vertical wind and thermodynamic profiles in the TC environment (the "synoptic flow") would provide improved operational guidance to human forecasters.

The data obtained during the 19 P-3 research missions conducted for this purpose through 1996 helped to reduce errors in TC track forecasts significantly (as much as 30\%) in global and regional dynamical models (Burpee et al. 1996). In addition, Shapiro and Franklin (1995) used an analysis of Hurricane Gloria (1985) synoptic flow data to diagnose the potential vorticity structure of a TC and to describe its dynamics, wind balance, and interaction with the environmental flow. Franklin et al. (1996) used analyses of all the synoptic flow dropwindsonde data to document the existence of beta gyres and investigate their impact on TC motion.

The success of this research program led to the development of a new generation of dropwindsonde (Hock and Franklin 1999) and the acquisition of a high-altitude jet aircraft (the Gulfstream-IV SP) as a dedicated operational platform to conduct synoptic surveillance missions. These operational flights, along with concurrent research into optimal targeting and sampling strategies and data assimilation, continue to improve National Centers for Environmental Prediction (NCEP) operational global model track forecasts significantly (Aberson 2003). A complete G-IV flight and the required dropwindsondes cost about $\$ 40,000$, far less than the estimated average of $\$ 1$ million needed to evacuate just one mile of coastline for landfall (Whitehead 2003). ${ }^{2}$

WIND. From 1962 to 1983, NOAA and its predecessors undertook an ambitious experimental program of TC modification, known as Project STORMFURY (Willoughby et al. 1985) in hopes of artificially invigorating convection in rainbands to compete with the eyewall for the high-energy inflowing air and thus reduce the maximum wind speed. The hypothesis was that supercooled water in TCs could be seeded with silver iodide to increase convection in rainbands. To investigate the hypothesis, the Forward Scattering Spectrometer Probe (FSSP) and two-dimensional optical array probes, devices to measure cloud particle sizes, types, and numbers, were installed on the P-3s. In early P-3 flights in major hurricanes, the clouds above the melting level were found to be composed mostly of ice particles, and supercooled liquid water was very rare. Copious graupel, frozen drops, and other ice particles were observed (Black and Hallett 1986). Thus, artificial cloud seeding would have no effect, and this was one reason that efforts to modify intensity in Project STORMFURY ended (Willoughby et al. 1985). An era of unprecedented observation of the TC and its environment with the goal of improving intensity forecasts ensued.

Tropical cyclone intensity change has long been known to be the result of a combination of internal dynamics, atmospheric environmental influences, and the impact of the ocean below. Accurate forecasts of intensity change first require accurate diagnosis of current intensity.

Surface wind measurements. Accurate specification of 1-min maximum surface wind speed and its location and the distribution of surface gale $\left(18 \mathrm{~m} \mathrm{~s}^{-1}\right)$

\footnotetext{
${ }^{2}$ Whitehead (2003) found that the evacuation cost depended upon population and storm intensity. The average cost in North Carolina was up to $\$ 1$ million per six miles. The population density used in that study was 608 people per coastal mile. Since other areas along the U.S. Gulf and East Coasts are more densely populated than the North Carolina coast, the average value of $\$ 1$ million per mile remains a good estimate, and may be low for densely populated states such as Florida.
} 
and hurricane $\left(33 \mathrm{~m} \mathrm{~s}^{-1}\right)$ force winds are essential for operational National Hurricane Center (NHC) intensity and structure forecasts, applications such as storm surge modeling (Jelesnianski et al. 1992) and insured loss estimation models (Malmquist and Michaels 2000). The maximum 1-min surface wind speed is the official NHC intensity estimate and determines to a large degree the extent of emergency preparations and evacuations needed for each TC landfall. Significant progress in documenting TC boundary layer kinematic structure has occurred (e.g., Powell 1980; Powell et al. 1991, 1996; Powell and Houston 1996). However, the lack of in situ surface observations in the eyewall and uncertainty in the relationship between flight-level and surface wind speeds limited the accuracy of maximum 1-min surface wind speed diagnosis. Until recently, Powell and Black (1990) made the only systematic study comparing flight-level and surface wind speeds; the dearth of observations of surface wind with speed greater than minimal hurricane force limited the applicability of the results to weak TCs.

Dropwindsondes released from the P-3s in 1997 provided the first high-resolution wind and thermodynamic profiles in a TC eyewall. Research and operational aircraft since have obtained more than 1000 such profiles. Franklin et al. (2003a) showed that the mean surface to $700 \mathrm{hPa}$ (the standard flight level for reconnaissance aircraft in hurricanes) wind speed ratio was about $90 \%$ in the eyewall in several hundred over-ocean profiles. They determined an adjustment factor for TC flight-level wind interpretation: without additional information, NHC operationally assesses surface maximum 1-min wind speed estimates to be about $90 \%$ of the peak 10 -s wind speed observed at $700 \mathrm{hPa}$. This new understanding of TC boundary layer wind and better methodology for adjusting flight-level wind speed measurements to the surface also is applied to historical TC reanalysis, including the upgrade of Hurricane Andrew to a Saffir-Simpson hurricane scale category 5 at landfall in southeast Florida (Landsea et al. 2004a)

Dropwindsonde data in major hurricanes suggest that the previous understanding of TC boundary layer physics, and therefore numerical model physical parameterization schemes, was not complete. In particular, Powell et al. (2003) found much smaller than expected roughness lengths, leading to a reduction of the drag coefficient for major hurricanes over the open ocean. This was hypothesized to be due to formation of a sea foam layer, which could help provide a "slip" surface between the ocean and the atmospheric boundary layer, allowing for faster surface wind speed.
Internal dynamics. Observations along P-3 flight tracks and from airborne radar substantially improved the basic understanding of TC structure and its relationship to intensity change. Successive aircraft penetrations of individual TCs enabled investigation of their evolution above what is possible during short, infrequent encounters with conventional land-based observing platforms. To this end, Willoughby and Chelmow (1982) developed an objective algorithm to determine TC center positions necessary for the accurate placement of data into a storm-relative coordinate framework, enabling much of the following TC structure research and internal dynamics research.

Symmetric Structure. At the beginning of the P-3 era, the TC was considered to be an axisymmetric vortex with convergence at low levels and divergence high in the eyewall and rainbands, upward motion within these features, and compensating subsidence in the eye and outside the vortex. The eyewall was assumed to be nearly vertical, and horizontal winds were assumed to be constant, up to midlevels (Simpson 1952). Observations obtained from the P-3 allowed for refinement of descriptions of the axisymmetric structure of TCs, and also for the first understanding of higher-wavenumber features.

Using airborne radar reflectivity data, Jorgensen (1984a,b) provided a more accurate description of the symmetric eyewall and rainband structure than was previously available. The largest updrafts were located radially inward from the wind and reflectivity maxima in the eyewall that slope radially outward with height (Jorgensen 1984a). Adjacent rainbands were more cellular than the eyewall and lacked consistent updrafts and distinct wind speed maxima at flight level (Jorgensen 1984a). Jorgensen (1984b) documented the TC eyewall structural evolution during coordinated eyewall penetrations by the $\mathrm{P}-3 \mathrm{~s}$ and the NOAA C-130. ${ }^{3}$ An eyewall radius-height schematic (Fig. 1) from these studies depicted the eyewall and its associated wind speed maximum, the relative positions of clouds and radar features, the regions of in- and outflow, and the location and strength of up- and downdrafts. Although the schematic did not describe asymmetries, and Marks and Houze (1987) subsequently showed that the maximum tangential wind was not inside the reflectivity maximum at all levels, the diagram still is representative of mean mature axisymmetric TC structure.

\footnotetext{
${ }^{3}$ NOAA used a C-130 for TC research before and during the first few years of P-3 operations.
} 


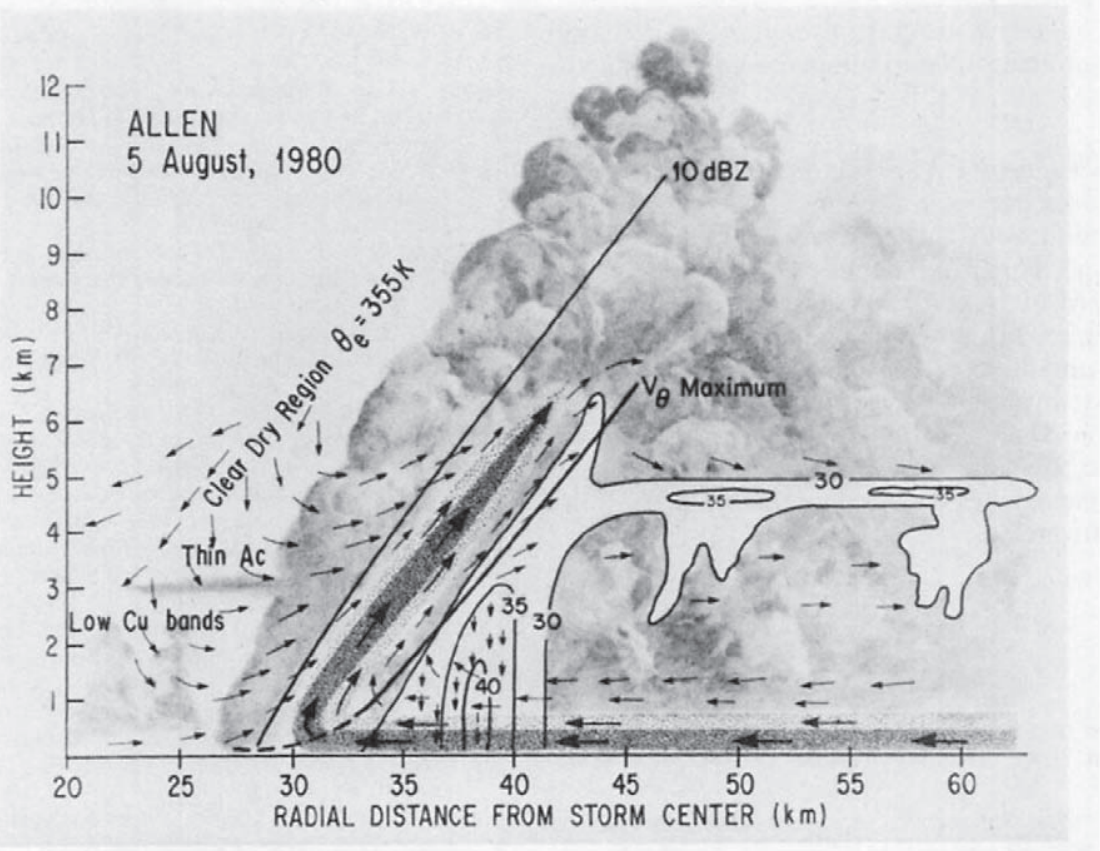

Fig. I. Schematic cross section depicting the locations of the clouds and precipitation, radius of maximum wind, and radial-vertical airflow through the eyewall of Hurricane Allen on 5 August 1980, from Jorgensen (1984b). The downward motion in the eye was based on estimates of radial divergence, and the downdrafts within the high rainfall rate region were inferred from vertical velocity time series from the individual passes. Reflectivity (dBZ) contours were based on a composite using 15 passes, although there was considerable pass-to-pass variability. The slope of the clouds on the inside edge of the eyewall was based on radar minimum detectable signal analysis, aircraft altimeter readings, photography and observer notes. Dark shading denotes the location of the largest radial and vertical velocities.
Doppler horizontal wind analysis assuming that features were stationary during the observation time. This allowed for the first description of mesocyclones associated with potentially destructive local wind speed maxima superimposed on the basic flow. Marks and Houze (1987) first documented the three-dimensional kinematic asymmetric eyewall structure with another pseudo-dual-Doppler analysis. They extended the composite structure of Jorgensen (1984b) to document the outwardly sloping tangential wind maximum comprising the primary circulation; deep low-level inflow, outflow above $10 \mathrm{~km}$, and rising motion in the eyewall sloping outward with height characterized the secondary circulation. Convective-scale up- and downdrafts within the eyewall were inferred us-

Willoughby (1990a), Willoughby and Rahn (2004), and Willoughby et al. (2006) constructed a database of over 900 radial flight-level profiles of basic meteorological parameters in TCs. The axisymmetric tangential wind above the boundary layer in TCs was in approximate gradient balance (Willoughby 1990b), explaining the outward slope of the eyewall with height, descent of air within the eye, and lowertropospheric inflow outside. Viltard and Roux (1998) used a retrieval algorithm on a dual-Doppler (two aircraft flying orthogonal tracks across the TC at nearly the same time) analysis to infer the TC thermal structure and confirmed the gradient and hydrostatic balance of the basic, symmetric flow.

Asymmetric structure. Using the first Doppler radar measurements obtained in a TC, Marks and Houze (1984) described for the first time important asymmetric TC structure characteristics. Data from orthogonal flight legs from one aircraft were combined into a three-dimensional pseudo-dual- ing Doppler measurements at vertical incidence after the removal of aircraft vertical motion and estimated particle fall speeds. With the analysis, particle trajectories could be followed throughout the circulation to describe the TC water budget. They concluded that this organized structure makes the TC more predictable than other tropical convective systems and allows for accurate numerical modeling of TCs. Marks et al. (1992) refined and extended this analysis, deriving vertical motion from mass mentation of the three-dimensional TC core wind field at $10-25-\mathrm{km}$ radial distance and 1-km scales in the horizontal and vertical, respectively. Asymmetries in the radial wind that varied with height were described for the first time, and these asymmetries were shown to contribute to the manner in which different air masses entered and exited the vortex and thus aided in intensity change.

Reasor et al. (2000) first documented TC mesoscale eyewall temporal evolution with seven detailed true continuity, and providing the first complete docu- 
dual-Doppler analyses during a 3-h period, focusing on the temporal evolution of asymmetries and the response of the vortex to increasing vertical shear of the horizontal wind. They provided the first evidence of vortex Rossby waves outside the eyewall, an important confirmation of analytical and numerical studies of TC intensity change (Montgomery and Kallenbach 1997; Moller and Montgomery 1999, 2000).

RAINBANDS AND CONCENTRIC EYEWALLS. Concentric eyewall cycles are an important means by which the intensity of mature TCs is modulated. Willoughby et al. (1982) used P-3 flight-level and reflectivity data to describe the evolution of concentric eyewalls that contract due to latent heat release (Shapiro and Willoughby 1982; Willoughby 1990a). Figure 2 shows the classical evolution of concentric eyewall features and their impact on TC intensity in Hurricane Gilbert (1988). Outer convective rings formed around the preexisting one, contracted, and strangled the original eyewall, causing weakening. TCs with a single, vigorous, and symmetric convective ring strengthened rapidly, whereas TCs with weak or asymmetric convective rings underwent episodic intensification. This natural intensity modulation was similar to intensity changes seen after project STORMFURY seeding missions, and was a second reason that efforts to modify TC intensity in Project STORMFURY ended (Willoughby et al. 1985). Roux and Viltard (1995) employed the extended velocity track display [EVTD; Roux and Marks (1996); from the VTD technique of Lee et al. (1994)] to dual-Doppler data to document weakening (strengthening) updrafts of an inner (outer) eyewall in time, and downward motion both inside and outside the outer eyewall at upper levels. Dodge et al. (1999) used airborne Doppler radar data to document the kinematics of the concentric eyewalls. The vertical profile of tangential wind in the inner eyewall was more erect than that in the eyewalls of weak storms, with wind $>50 \mathrm{~m} \mathrm{~s}^{-1}$ extending from the surface to $12 \mathrm{~km}$. The radial flow suggested that the outer eyewall had a more vigorous secondary circulation (strong radial inflow) than the inner eyewall, thus explaining its eventual demise. Though these cycles are now frequently observed globally, accurate forecasts of the timing and resultant intensity changes, remain elusive.

Willoughby et al. (1984) described the flow associated with rainbands that rotate about and were connected to the inner convective ring. These rainbands intensify and initiate the eyewall cycle by developing into a new, outer eyewall. Barnes et al. (1983) described the mesoscale thermodynamic and kinematic structure of one such large rainband. The frequency of cellular convective precipitation decreased, and stratiform precipitation increased, along the rainband toward where it spiraled toward the eyewall. Air with relatively low equivalent potential temperature in the subcloud layer, the result of outflow from strong convective activity within the rainband, was observed outside the rainband, especially between the rainband and the eyewall. This air could stabilize the eyewall lapse rate and decrease TC intensity. Samsury and Zipser (1995) described the relationship between the rainbands and wind speed maxima associated with outer eyewalls. Almost all such maxima were

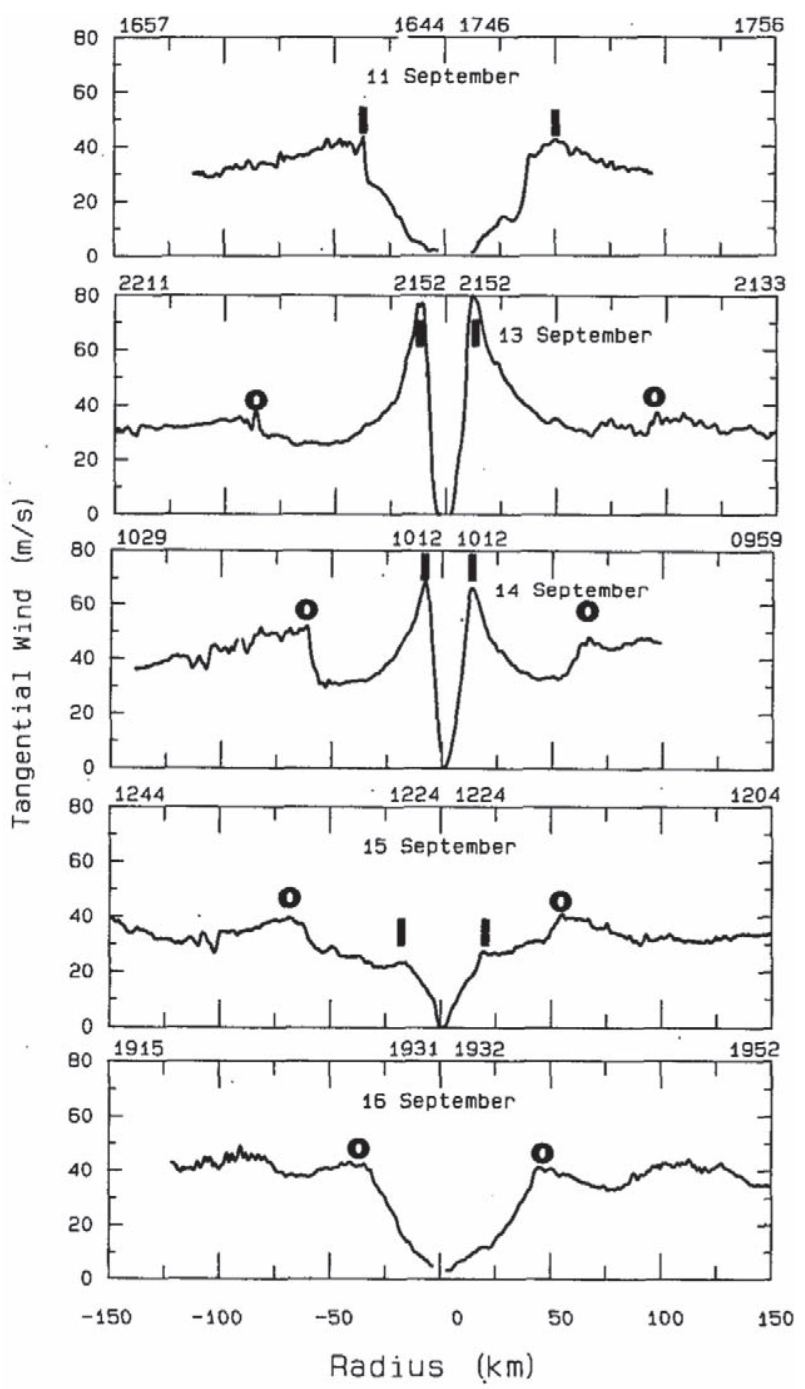

FIG. 2. Flight-level tangential wind speed from the south-north traverses through the center of Hurricane Gilbert (1988). Bold Is and Os denote the location of the inner- and outer-eyewall wind maxima, respectively. Times (UTC) at the beginning of each radial pass are at the top of the panels. From Black and Willoughby (1992). 
associated with mesoscale rainband features (an outer eyewall), but $>70 \%$ of rainbands did not have a pronounced wind speed maximum at flight level. Powell (1990a,b) confirmed the results of Barnes et al. (1983) and incorporated airborne Doppler radar and flight-level measurements into a complete description of the TC rainband structure, including locations of reflectivity maxima and minima, updrafts and downdrafts, and other kinematic and thermodynamic structures. Further research into intensity changes possibly related to dynamical interactions between the eyewall and rainbands was conducted in cooperation with the National Science Foundation in the 2005 Hurricane Rainband and Intensity Experiment (RAINEX; Houze et al. 2006).

EYE. Data from P-3 aircraft were able to show the extent of mixing of air between the eye and eyewall and its implications. Using eye soundings, Willoughby (1998) found that the air aloft in the eye was clear, warm, and dry, and overlays an inversion below which moist, cloudy air resides. The air above the inversion remains there for long periods, subsides only a few kilometers, and mixes weakly with moist

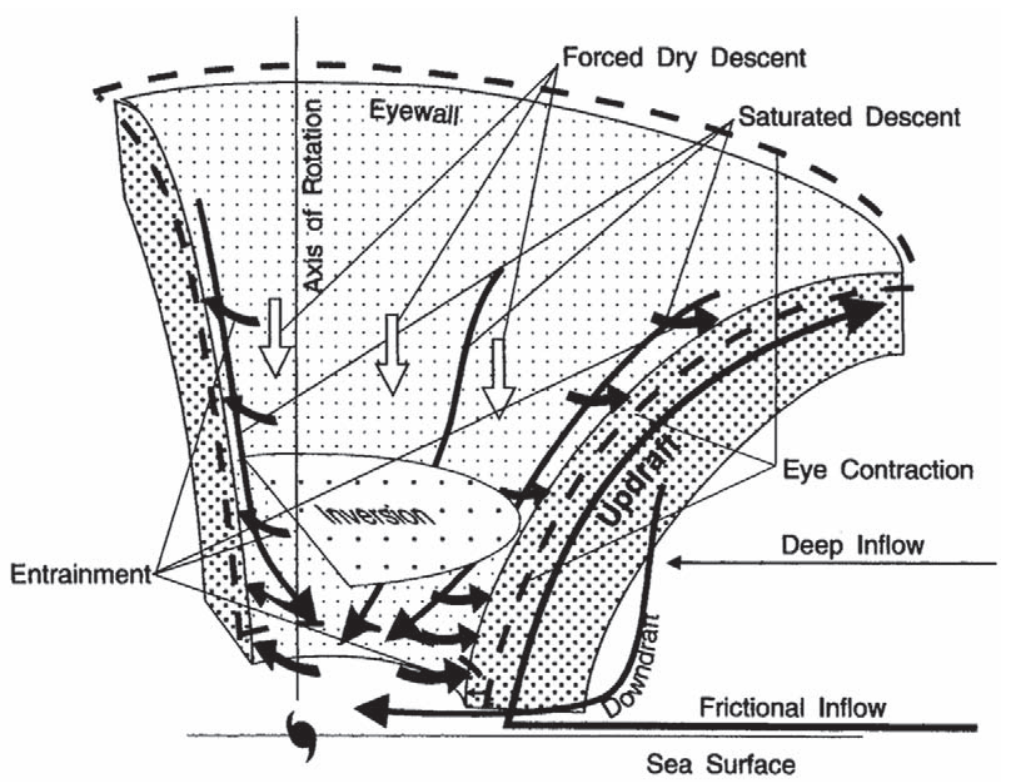

Fig. 3. Schematic of the secondary flow in the eye and eyewall of a TC. The inflow feeds the buoyancy-driven primary updraft and outflow in the eyewall. Inflow under the eyewall was derived from convective downdrafts. It, and evaporatively driven descent along the inner edge of the eyewall, feed moist air into the eye below the inversion. Gradual thermodynamically or dynamically driven descent of dry air inside the eye warms the air column adiabatically. Convection draws mass from the bottom of the eye into the eyewall, forcing descent. Balance between moist air production and loss to the eyewall determines the rate of rise or fall of the inversion. From Willoughby (1998). air from the eyewall. The air below the inversion comes from the low-level inflow and mixes easily with the eyewall (Fig. 3). Kossin and Eastin (2001), using flight-level and dropwindsonde data, suggested that barotropic instability could cause more mixing between the eyewall and eye than Willoughby (1998) found. This mixing of high entropy air from the eye into the eyewall has since been found to be an additional intensification mechanism for TCs (Persing and Montgomery 2003). As theoretical and modeling studies continue to suggest varying amounts of mixing between the eye and eyewall, further observations on small scales must be obtained to confirm or refute hypotheses (Montgomery et al. 2006, Aberson et al.

Atmospheric environmental influences. The mechanism by which vertical shear of the horizontal wind impacts TC structure and intensity, and vice versa, has been somewhat clarified by data from the P-3s. Franklin et al. (1993) incorporated dropwindsonde, flightlevel, and airborne Doppler radar data, along with satellite and rawinsonde observations, to describe the kinematic structure of Hurricane Gloria (1985) and its environment. This analysis remains the most comprehensive single snapshot of the structure of a TC and its environment. Gloria had an unusual structure with the eyewall sloping slightly inward with height to about $500 \mathrm{hPa}$ where the wind speed was greatest. They related persistent asymmetry of the eyewall convection to the vertical shear of the horizontal wind.

Marks et al. (1992) first documented a vortex tilt with height and the relationship of this tilt to shear. Reasor et al. (2000) used true dualDoppler analyses to investigate the temporal response of the vortex to changes in the vertical shear of the horizontal wind. Black et al. (2002) used reflectivity, three-dimensional Doppler analysis and vertical incidence, and flight-level data to investigate the relationship between shear, sea surface temperature, asymmetric structure, and intensity change. They described the mesoscale processes and asymmetric eyewall structure in a sheared environment and produced a schematic (Fig. 4) represent- 
ing the eyewall structure in relation to the large-scale shear. They showed that relatively dry air due to the impact of shear was able to penetrate the eyewall and lead to weakening of the TC, and that shear prevented eyewall convection from completely orbiting the eye, also contributing to intensity changes.

Six aircraft [the two NOAA P-3s, the NOAA G-IV, the National Aeronautics and Space Administration (NASA) DC-8 and ER-2 aircraft, and an Air Force C-130-Hercules aircraft] flew simultaneously in and around Hurricane Humberto (2001) on two consecutive days. This new dataset includes atmospheric dynamic and thermodynamic data through the depth of the troposphere as well as upper-ocean data (Feuer et al. 2002) and is the most comprehensive dataset obtained in a TC to date (Fig. 5).

Air-sea interaction. Careful analysis of data from dropwindsondes and other expendable instruments released from the P-3s is elucidating the ways in which TCs interact with the underlying ocean to cause intensity changes. Cione et al. (2000) and Cione and Uhlhorn (2003) found that low-level inflow into the TC center was not isothermal, that surface moisture was not constant, and that the air near the surface was not in thermodynamic equilibrium with the sea. The surface air temperature drops as the air flows toward the TC center; this drop occurs far from the eyewall where the largest pressure drops occurred, so the change is not adiabatic. This allows surface heat and moisture fluxes to be much higher near the eyewall than further away; the fluxes are thus greater than previously believed, and more energy is provided to the TC from the underlying ocean. Since the eyewall is nearly saturated, the surface air temperature near the TC center was relatively constant with distance from the center despite the potential for spray-induced evaporational cooling and adiabatic expansion. Black and Holland (1995) and Wroe

Fig. 5. Flight tracks of the six aircraft observing Hurricane Humberto and its stratospheric, tropospheric, and upper-oceanic environment 23-24 Sep 200I. The red and black lines are the two NOAA P-3s; the green line is the NOAA G-IV; the blue line is the NASA DC-8; the violet line is the NASA ER2; and the orange line is an Air Force C-130-H.

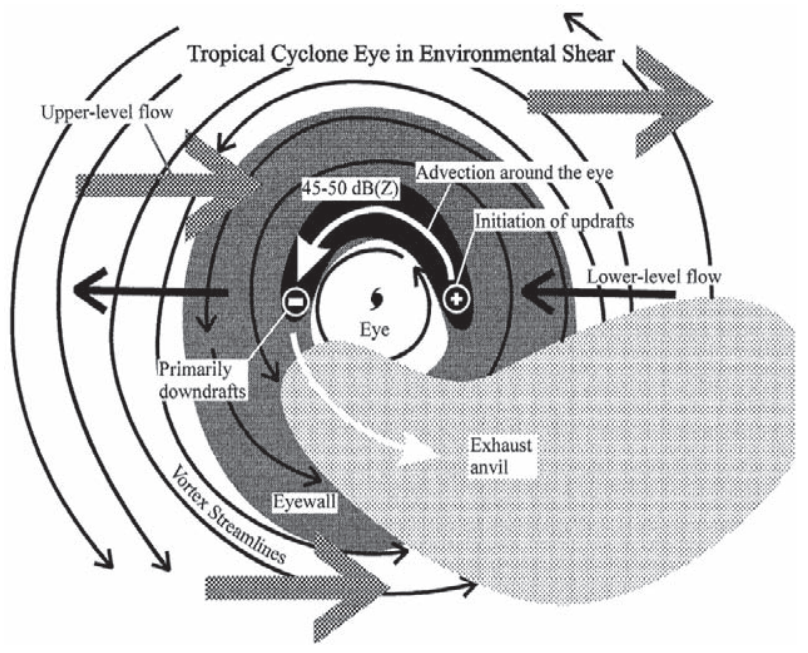

Fig. 4. Schematic of shear-induced convective asymmetry from Black et al. (2002). The two solid black arrows and the three stippled arrows indicate the low-level and upper-level environmental flows, respectively. Convective cells form upwind of the down-shear side of the eyewall and were advected around the eye into the region to the left of the shear vector. Precipitation-driven downdrafts begin about $90^{\circ}$ to the left of the shear vector. By the time the cells reach the up-shear side of the eyewall, they ascend through the $0^{\circ} \mathrm{C}$ isotherm and downdrafts predominate. As the cells move into the region to the right of the shear vector, most condensate freezes or falls out of the active updrafts. The unloaded updrafts accelerate upward, detach from the eyewall, and approach the tropopause as they rotate through the region to the right of the shear.

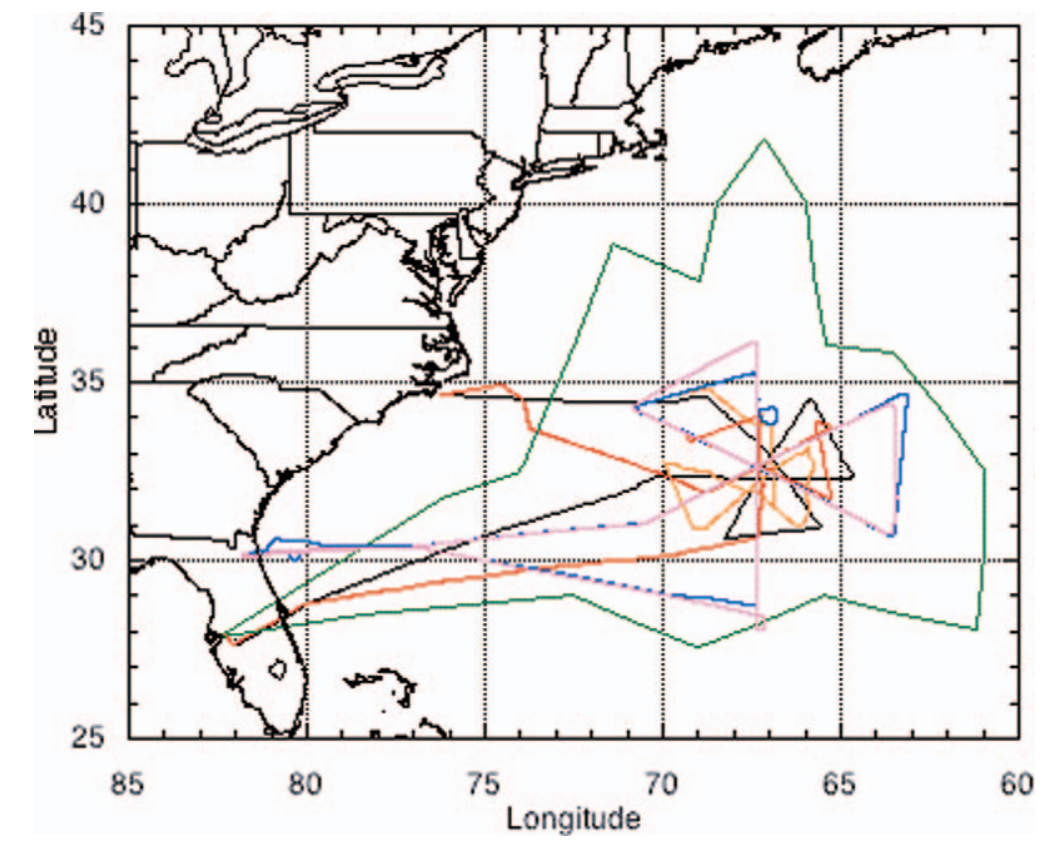


and Barnes (2003) confirmed these observations and worked out the energetics within rainbands and near the eyewall. They also confirmed the result of Gamache et al. (1993) that unsaturated convective downdrafts near and under the eyewall may dry and evaporatively cool the air near the surface. Composite analyses from Cione et al. (2000) and Cione and Uhlhorn (2003) are shown in Fig. 6.

Black (1983) showed that, of 19 TCs, those over an oceanic mixed layer depth (MLD) $<50$ m produced crescent-shaped decreases of as much as a few kelvin in the sea surface temperature. The cooling was concentrated in the right rear quadrant (relative to motion in the Northern Hemisphere), with the maximum occurring a short distance outside the eyewall. This implies that surface air flowing inward over relatively cool water can lessen the enthalpy flux from the ocean into the atmosphere, thereby becoming cooled and reducing buoyancy in the eyewall. The left front quadrant had only a very small SST decrease. Black et al. (1988) and Shay et al. (1992) further documented the significant impact TCs have on the upper ocean. Cione and Uhlhorn (2003) showed that SST reduction near the TC center is modest $(\sim 0.2-1.2 \mathrm{~K})$, and that much of the observed $4-6-\mathrm{K}$ cooling occurs long after TC passage. The magnitude of the SST change was statistically linked to subsequent intensity changes, suggesting that SST measurements in regions over which the TC core will pass, and during passage, will aid in intensity forecasts. These issues were investigated in flights supporting the Coupled Boundary Layer Air-Sea Transfer (C-BLAST) experiment during the 2000-04 Atlantic hurricane seasons (Black et al. 2006).

Life cycle. The vast majority of P-3 airborne research was accomplished on mature TCs over open water. Partly because of the difficulty in forecasting such events, research on the genesis and lysis stages of tropical cyclones has lagged. The P-3s participated in two international field campaigns ${ }^{4}$ of the Tropical Ocean Global Atmosphere (TOGA) Program in the equatorial western Pacific in 1987 [the Equatorial Monsoon Experiment (EMEX)] and in 1992-93 [the Coupled Ocean-Atmosphere Response Experiment (COARE)]. Though TCs were not the primary focus of either field campaign, the goals of EMEX were to document the kinematic structure of mesoscale tropical convective systems that sometimes develop into TCs with airborne Doppler radar and other new observing platforms, and to investigate the physical mechanisms responsible for the convective and stratiform components of these cloud systems. The P-3s

\footnotetext{
${ }^{4} \mathrm{~A}$ third international collaboration at that time was more informal, involving Soviet aircraft flying from Cuba (Black and Lidnetskii 1993).
}
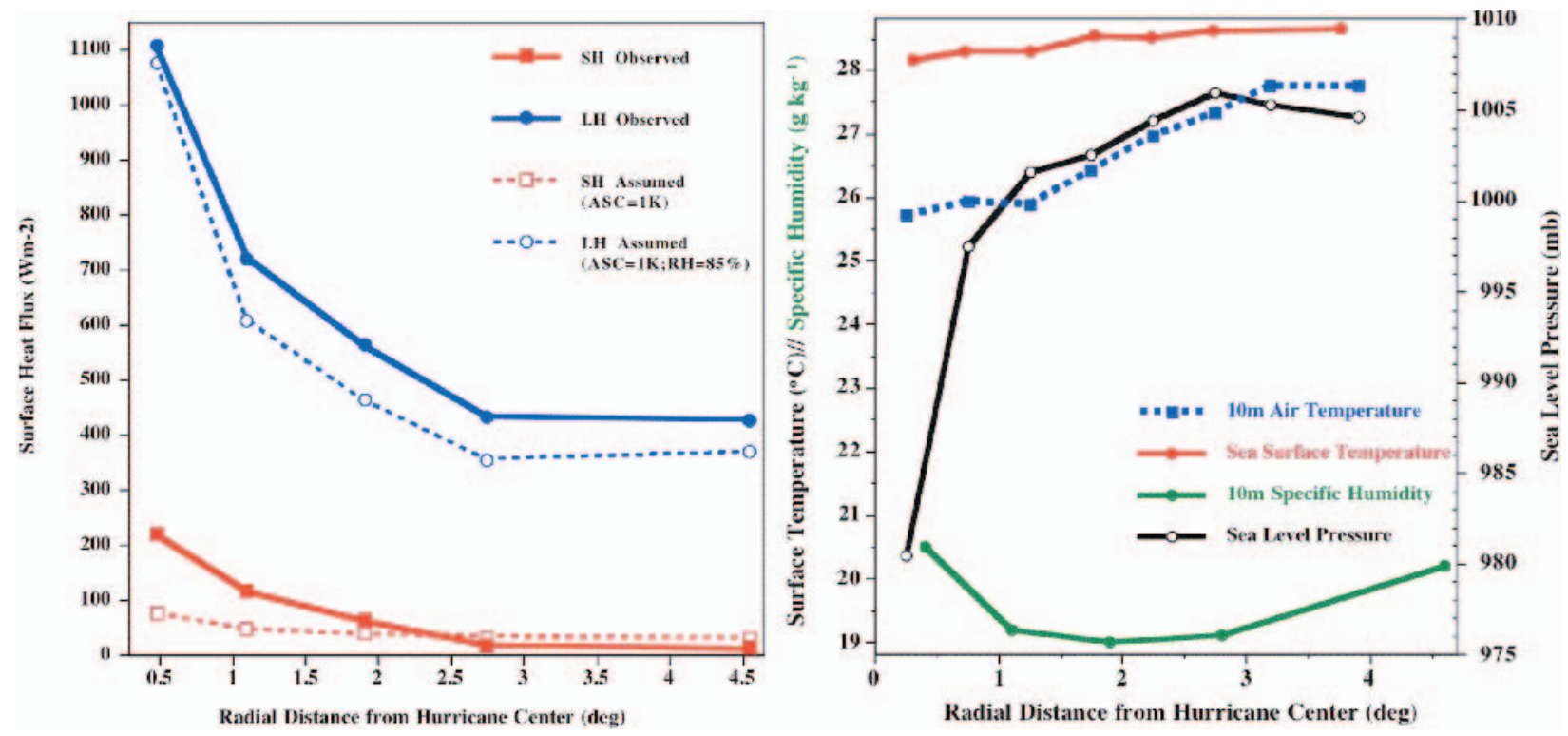

FIG. 6. Composite analyses of TC boundary layer fluxes and TC thermodynamic structure from Cione et al. (2000) and Cione and Uhlhorn (2003): (left) radially averaged $10-\mathrm{m}$ air temperature, sea surface temperature, $10-\mathrm{m}$ specific humidity, and sea level pressure as a function of distance from the TC center, and (right) radially averaged surface sensible (SH) and latent heat (LH) fluxes calculated from observations using standard bulk estimates; $\mathrm{SH}$ and $\mathrm{LH}$ flux values assume a constant I-K air-sea contrast and $85 \%$ surface relative humidity. 
documented a mesoscale convective system as it was developing into Cyclone Irma (Webster and Houze 1991). COARE was designed partially to investigate the atmospheric processes that organize convection in the tropical warm pool and coupling of the ocean and the atmosphere there (Webster and Lukas 1992; Yuter et al. 1995). In 1991, the P-3s participated in the Tropical Experiment in Mexico (TEXMEX) and observed the transformation of a mesoscale convective system into Hurricane Guillermo (Bister and Emanuel 1997). Further investigations of tropical convection and its relationship to tropical cyclogenesis, intensity change, and rainfall were conducted in cooperation with NASA in three field campaigns-the Third Convection and Moisture Experiment (CAMEX-III) in 1998, CAMEX-IV in 2001, and the Tropical Cloud Systems and Processes (TCSP) experiment in 2005 (Kakar et al. 2006).

The end of the TC life cycle generally involves either the extratropical transition (ET) of TCs or landfall. The P-3s have only recently begun to study ET with two sets of missions. The first set was conducted in Tropical Storm Odette during the 2003 North Atlantic THORPEX Regional Campaign (Langland 2005), and the second, with more successful observations, was taken in collaboration with Environment Canada in Hurricane Ophelia before it made landfall in Nova Scotia, Canada, in September 2005.

Before the Next-Generation Weather Radar (NEXRAD) program became operational, radar reflectivity during landfall events was recorded by HRD scientists for research purposes. With the advent of land-based Doppler radar along the coastline, HRD undertook a series of airborne experiments along the coast and inland with the goal of creating dual-Doppler analyses of the TC wind field at landfall and to describe its evolution. Such aircraft missions also were coordinated with teams from the University of Oklahoma and the NOAA/National Severe Storms Laboratory who deployed Doppler on Wheels near the landfall location. As teams from the Florida Coastal Monitoring Program, Texas Tech University, Texas A\&M University, the University of Louisiana at Monroe, and the Center for Severe Weather Research began deploying wind towers and mobile Doppler radars during landfall, these experiments were expanded to coordinate with these teams to gather wind profiles from dropwindsondes near the deployment locations. During Hurricanes Fran (1996) and Dennis (2005), data were gathered well inland to observe the change in TC structure after landfall.

\section{VERTICAL MOTIONS AND RAINFALL.} Jorgensen et al. (1985) first documented the vertical velocity structure of TCs from flight-level data. Black et al. (1996) extended this analysis throughout the depth of the storm. Most vertical motion cores were small in area ( $<5 \mathrm{~km}$ across), and the distribution of vertical motion was broader in the eyewall than elsewhere, with updrafts being wider and stronger than downdrafts. Eyewall updrafts exhibited a pronounced outward tilt with height, and downdrafts were vertically aligned. Maximum upward mass flux was at about $1 \mathrm{~km}$ above the surface, suggesting that boundary layer convergence was efficient in producing upward motion. More recently, Eastin et al. (2005a,b) calculated the buoyancy of convective motions in the eyewalls and rainbands of intense TCs. They confirmed that most small-scale convective cores occurred within regions of weak mesoscale ascent and that these cores (both upward and downward) were associated with regions of small, positive total buoyancy. The updraft cores took up only about $5 \%$ of the total area, but accounted for more than $40 \%$ of the total upward momentum flux in their sample. Updrafts and downdrafts $>20 \mathrm{~m} \mathrm{~s}^{-1}$ were observed for several hours in Hurricane Emily (1987). The strong downdrafts had insufficient precipitation to account for the downdraft strength, which was due to air accelerating down surfaces of constant angular momentum as condensed water evaporated (Black et al. 1994). This vertical momentum could be tilted into the horizontal accounting for subsequent vortex intensification.

Jorgensen and Willis (1982) compared hydrometeor particle measurements with P-3 airborne radar data to derive a reflectivity $(Z)$-rainfall $(R)$ relationship for TCs, thus allowing rainfall estimation from radar. The relationship was the same for both convective and stratiform TC rain, but was different at high rainfall rates than that for other convective precipitation. Marks (1985) documented the relative importance of convective and stratiform processes and described the three-dimensional TC precipitation distribution and evolution using this $Z-R$ relationship from the P-3 radars. Tropical cyclone intensity had little effect on total rainfall or latent heat release, but the mean rainfall rate in the eyewall increased with intensity. Maximum total rainfall occurred when the TC had concentric eyewalls, and most rain fell ahead of the eye. Mean rainfall rates within the eyewall were typically at least 6 times that elsewhere but only contributed about $40 \%$ of the total rainfall.

Houze et al. (1992) combined reflectivity, Doppler wind observations, flight-level observations, and 
cloud microphysical measurements to document the mesoscale ice particle distribution in and near the eyewall of Norbert (1984). Marks and Houze (1987), Houze et al. (1992), and Marks et al. (1992) described the three-dimensional ice particle trajectories originating in eyewall updrafts, and Gamache et al. (1993) used two microphysical retrieval methods to document the three-dimensional bulk water budget in the eyewall for the first time, a first step toward diagnosis of the entire storm energy budget.

To determine the conditions necessary for the rare occurrence of lightning in TCs, electrical field mills were installed on the P-3s in 1990 to measure the vertical and horizontal components of the electrical field in clouds. Black and Hallett (1999) described the microphysical characteristics of electrified and nonelectrified clouds. Updrafts $>10 \mathrm{~m} \mathrm{~s}^{-1}$, supercooled cloud water content $>0.5 \mathrm{~g} \mathrm{~m}^{-3}$, and graupel all were necessary for sufficient electric charge separation to generate lightning. This study provides the first glimpses of the relationship between storm microphysics and dynamics. They described TC precipitation processes, cloud distribution, and preferred regions for charge separation in a schematic (Fig. 7).

CONCLUSIONS AND THE FUTURE. The first 30 years of NOAA P-3 aircraft research in TCs provided much of the current understanding of
TC structure, motion, and intensity change. More than 200 refereed articles and numerous conference and technical reports have been published utilizing data obtained by the P-3 aircraft in TCs. All of the data, including some analyses, are freely available to interested scientists online at www.aoml.noaa. gov/hrd. Some of the most important achievements and contributions to operational forecasts include the following:

- Additional wind, pressure, mass, temperature, and humidity profiles in the TC environment led to significant improvements to TC track forecasts. This finding led to the acquisition of the NOAA G-IV for operational surveillance missions and the commensurate development of the operational NOAA Winter Storms Reconnaissance program to improve high-impact midlatitude winter weather forecasts (Szunyogh et al. 2000, 2002). Other experimental field programs to improve high-impact weather forecasts, such as the Fronts and Atlantic Storm Track Experiment (FASTEX) and the current THORPEX: A Global Atmospheric Research Programme, have grown out of this program. The success has also led the National Science Council of Taiwan to initiate Dropsonde Observation for Typhoon Surveillance Near the Taiwan Region (DOTSTAR) to improve typhoon forecasts (Wu et al. 2005).

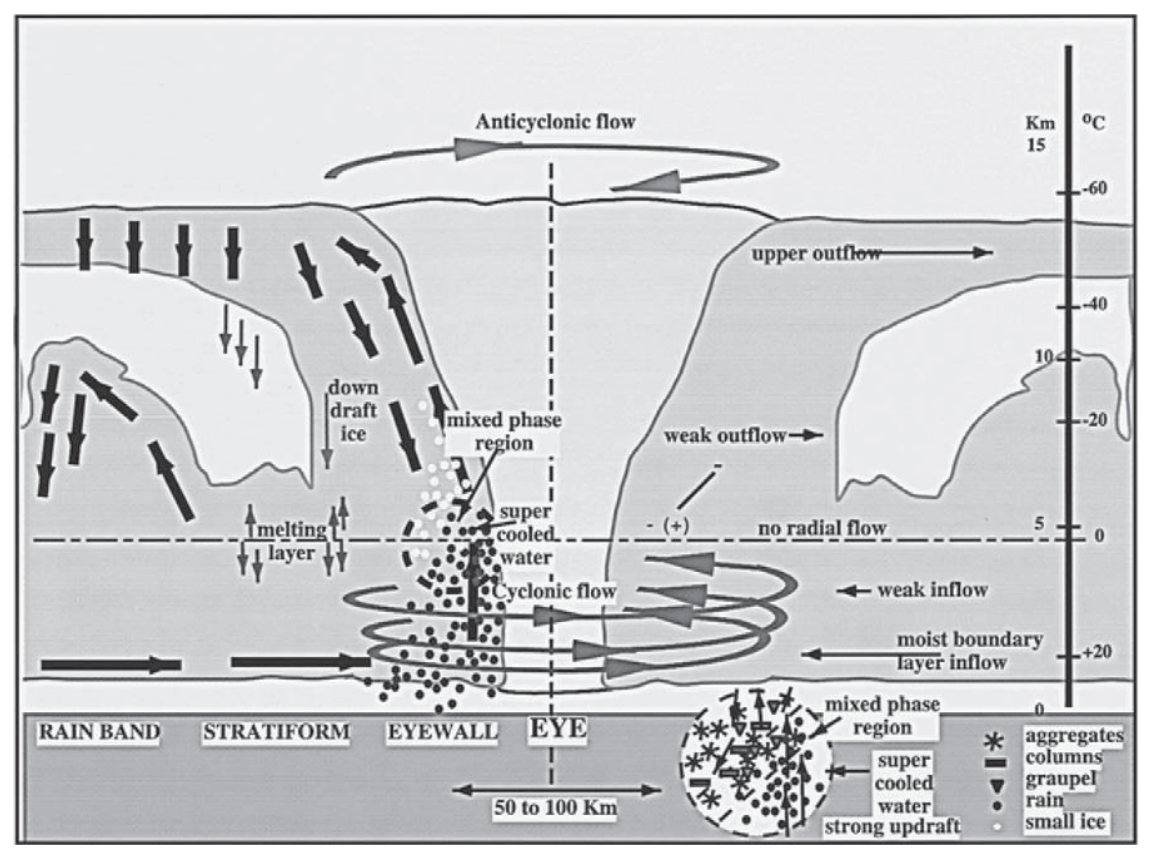

FIG. 7. Schematic of mature TC precipitation processes, cloud distribution, and preferred regions for charge separation. Sea surface and cloud-base temperatures were near $28^{\circ}$ and $22^{\circ} \mathrm{C}$, respectively. Typical vertical velocity near $0^{\circ} \mathrm{C}$ is $\mathbf{5 - 8} \mathrm{m} \mathrm{s}^{-1}$, and convection extends well above $-40^{\circ} \mathrm{C}$, the temperature for homogeneous ice nucleation. The inset shows where charge separation occurs in the horizontal gradient of vertical shear, limited in altitude by the lack of supercooled water above $-5^{\circ} \mathrm{C}$. White (black) dots indicate where small ice (water) particles exist. Arrows show axial and radial flow leading to hydrometeor redistribution. Fat arrows with elliptical tails represent the tangential circulation and the change from cyclonic to anticyclonic flow near the top of the TC and ice redistribution at midlevels. Thinner arrows show approximate radial and vertical winds, and the observed distribution of electric field polarity is shown. From Black and Hallett (1999). 
- Airborne reflectivity and Doppler radar analyses documented the symmetric TC structure, including concentric eyewall cycles that can modulate the intensity of mature TCs. Study of TC asymmetric structure was only in its infancy when the P-3 era began, and analysis of data collected during the P-3 flights allowed numerous studies of this structure and its importance in TC evolution. This has lead to increased understanding of internal dynamical processes causing intensity changes. The upcoming upgrade of the G-IV to include a Doppler radar system underscores the importance of these observations. Toward this end, Doppler wind analyses are currently made in real time onboard the P-3s and transmitted to NCEP in preparation for assimilation into nextgeneration hurricane forecasting models. This will enable, for the first time, accurate initialization of the TC vortex in operational numerical models and holds great promise for large improvements in TC intensity forecasts.

- Dropwindsondes released in 1997 provided the first look at vertical wind profiles in the boundary layer. Since then, data from dropwindsondes and the SFMR have greatly enhanced the diagnosis of current intensity and knowledge of the relationship between winds at flight level and at the surface where damage occurs. The existence of low-level wind speed maxima lessened the appropriateness of "vertical evacuation" plans in urban settings, and this new knowledge is an important component of the Atlantic Hurricane Database Reanalysis Project (Landsea et al. 2004b; Dunion et al. 2003).

- Analysis of data from airborne oceanic expendables released by the P-3s aided the description of the feedback between the temperature structure of the upper ocean and TC intensity. Such research is leading to improved implementation of physical parameterizations in operational and research coupled air-sea numerical TC models.

- Analysis of near-surface thermodynamic observations from dropwindsondes and AXBT data defined the structure of the air-sea interface in the TC.

- The P-3 microphysical data were used to disprove the hypothesis that seeding convective clouds could artificially manipulate TC intensity, as investigated during the STORMFURY project. These data, together with radar data, provided the first look at the relative importance of convective and stratiform precipitation processes in TCs.
- Instruments developed for the P-3s, such as SFMR and the GPS dropwindsonde, have provided important documentation of TC structure for research. In addition, such instrumentation has become integral to the TC warning process. Both instruments have been, or soon will be, installed on operational TC reconnaissance aircraft to aide in the warning process.

The historical objective of the NOAA Hurricane Field Program was the collection of data required to support analytical and theoretical TC studies designed to improve the understanding of TC structure and behavior. Whereas the P-3s initially provided TC location and intensity information, the gradual increase in the amount of aircraft data transmitted to the ground led to wider support of operations (Burpee et al. 1994). Improvements to telecommunications will allow for increases in the type and density of transmitted data, including upper-ocean temperature profiles and Doppler radar wind observations for assimilation into operational numerical models. Future Hurricane Field Program efforts will be geared toward improving TC track, intensity, and rainfall forecasts by providing these data in order to improve current operational numerical modeling systems and develop new ones (such as the Hurricane Weather Research and Forecast Model) and to understand intensity change and rainfall processes during the entire TC life cycle. This data collection is part of the development of a modeling system, and involves research into data assimilation, understanding and parameterization of physical processes, and model evaluation and validation with comprehensive TC datasets collected by the P-3s (Rogers et al. 2006).

Tropical cyclone track forecast errors have improved at about $1 \%-2 \%$ per year (McAdie and Lawrence 2000; Franklin et al. 2003b). Although in recent years TC intensity forecasts have improved slowly, they remain much less skillful than the track forecasts. This limited skill is problematic, particularly for systems approaching land that may potentially undergo rapid intensity changes during the time when emergency management officials issue evacuation and other precautionary orders to local residents. Further, TCs drop copious amounts of precipitation, even several hundred miles inland, after the wind speed decreases below hurricane force. This can produce an additional serious threat to society from freshwater flooding that, until Hurricane Katrina, had recently been the cause of the majority of TCrelated deaths (Rappaport 2000). Continued improvements in TC track, intensity, and rainfall forecasts 
are critical to emergency managers at the local, state, national, and international levels; mariners, including the U.S. Navy; NASA; and other U.S. federal agencies responsible for the well-being of millions of people and for billions of dollars of assets.

ACKNOWLEDGMENTS. The authors wish to thank the leadership and staff of NOAA's Aircraft Operations Center and its predecessors for their expert maintenance and piloting of the aircraft in potentially dangerous hurricane situations, and remember Jim McRory who was killed in a tragic accident during maintenance on 19 September 1979. We especially thank James McFadden for his program management throughout this period, and all of the engineers who kept the P-3s on the cutting edge of technology. The Chief, Aerial Reconnaissance Coordination, All Hurricanes (CARCAH) unit helped to coordinate all research and operational flights into TCs. The research program was ably led by the directors of HRD and its predecessors (Noel LaSeur, the late Stanley Rosenthal, Robert Burpee, Hugh Willoughby, and Frank Marks) and the directors of the Hurricane Field Program (Robert Sheets, Robert Burpee, Frank Marks, Michael Black, and Robert Rogers). Funding for the purchase of the aircraft and much of the instrumentation, as well as continued support for the hurricane program was provided by NOAA/Office of Atmospheric Research and other NOAA agencies. Jim Trout provided logistical assistance for many of the early flights. Neal Dorst compiled the information for Table 1. Garpee Barleszi, Peter Dodge, James Franklin, John Gamache, Stanley Goldenberg, Mike Jankulak, Jim Kossin, Paul Willis, and an anonymous reviewer provided very helpful comments on earlier versions of the manuscript.

\section{REFERENCES}

Aberson, S. D., 2003: Targeted observations to improve operational tropical cyclone track forecast guidance. Mon. Wea. Rev., 131, 1613-1628.

—, M. T. Montgomery, M. Bell, and M. L. Black, 2006: Hurricane Isabel (2003): New insights into the physics of intense storms. Part II: Extreme localized wind. Bull. Amer. Meteor. Soc., in press.

Barnes, G. M., E. J. Zipser, D. Jorgensen, and F. D. Marks, 1983: Mesoscale and convective structure of a hurricane rainband. J. Atmos. Sci., 40, 2125-2137.

— J. F. Gamache, M. A. LeMone, and G. J. Stossmeister, 1991: A convective cell in a hurricane rainband. Mon. Wea. Rev., 119, 776-794.

Baumgardner, D., and A. Korolev, 1997: Air speed corrections for optical array probe sample volumes. J. Atmos. Oceanic Technol., 14, 1224-1229.
Bister, M., and K. A. Emanuel, 1997: The genesis of Hurricane Guillermo: TEXMEX analysis and a modeling study. Mon. Wea. Rev., 125, 2662-2682.

Black, M. L., and H. E. Willoughby, 1992: The concentric eyewall cycle of Hurricane Gilbert. Mon. Wea. Rev., 120, 947-957.

—, R. W. Burpee, and F. D. Marks, 1996: Vertical motion characteristics of tropical cyclones determined with airborne Doppler radial velocities. J. Atmos. Sci., 53, 1887-1909.

- J. F. Gamache, F. D. Marks, C. E. Samsury, and H. E. Willoughby, 2002: Eastern Pacific Hurricanes Jimena of 1991 and Olivia of 1994: The effect of vertical shear on structure and intensity. Mon. Wea. Rev., 130, 2291-2312.

Black, P. G., 1983: Ocean temperature changes induced by tropical cyclones. Ph.D. thesis, The Pennsylvania State University, 278 pp.

— , and A. V. Lidnetskii, 1993: Meteorological fields in Hurricane Gilbert from data measured by flying meteorological laboratories. Meteor. Gidrol., 2, 1-19.

—, R. L. Elsberry, L. K. Shay, R. P. Partridge, and J. F. Hawkins, 1988: Atmospheric and oceanic mixed layer observations in Hurricane Josephine obtained from air-deployed drifting buoys and research aircraft. J. Atmos. Oceanic Technol., 5, 683-698.

—-, and Coauthors, 2006: Air-sea exchange in hurricanes: Synthesis of observations from the coupled boundary layer air-sea transfer experiment. Bull. Amer. Meteor. Soc., in press.

Black, R. A., and J. Hallett, 1986: Observations of the distribution of ice in hurricanes. J. Atmos. Sci., 43, 802-822.

— Tropical Cyclone Kerry (1979). Mon. Wea. Rev., 123, 2007-2028

— ricane. J. Atmos. Sci., 56, 2004-2028.

—, H. B. Bluestein, and M. L. Black, 1994: Unusually strong vertical motions in a Caribbean hurricane. Mon. Wea. Rev., 122, 2722-2739.

Burpee, R. W., and Coauthors, 1994: Real-time guidance provided by NOAA's Hurricane Research Division to forecasters during Emily of 1993. Bull. Amer. Meteor. Soc., 75, 1765-1783.

— J. L. Franklin, S. J. Lord, R. E. Tuleya, and S. D. Aberson, 1996: The impact of Omega dropwindsondes on operational hurricane track forecast models. Bull. Amer. Meteor. Soc., 77, 925-933.

Cione, J. J., and E. W. Uhlhorn, 2003: Sea surface temperature variability in hurricanes: Implications with respect to intensity change. Mon. Wea. Rev., 131, 1783-1796. 
— , P. G. Black, and S. H. Houston, 2000: Surface observations in the hurricane environment. Mon. Wea. Rev., 128, 1550-1561.

Davies, P., 2000a: Inside the Hurricane. Henry Holt and Company, 264 pp.

— 2000b: The Devil's Music: In the Eye of the Hurricane. Michael Joseph, 304 pp.

Davis, W. R., 1954: Hurricanes of 1954. Mon. Wea. Rev., 82, 370-373.

Dodge, P. P., R. W. Burpee, and F. D. Marks, 1999: The kinematic structure of a hurricane with sea level pressure less than $900 \mathrm{mb}$. Mon. Wea. Rev., 127, 987-1004.

Dunion, J. P., C. W. Landsea, S. H. Houston, and M. D. Powell, 2003: A reanalysis of the surface winds for Hurricane Donna of 1960. Mon. Wea. Rev., 131, 1992-2011.

Eastin, M. D., W. M. Gray, and P. G. Black, 2005a: Buoyancy of convective vertical motions in the inner core of intense hurricanes. Part I: General statistics. Mon. Wea. Rev., 133, 188-208.

,$- \ldots$, and $—, 2005 \mathrm{~b}$ : Buoyancy of convective vertical motions in the inner core of intense hurricanes. Part II: Case studies. Mon. Wea. Rev., 133, 209-227.

Feuer, S. E., J. F. Gamache, M. L. Black, F. D. Marks, and J. B. Halverson, 2002. A multiple aircraft experiment in Hurricane Humberto (2001). Part I: Wind fields. Preprints, 25th Conf. on Hurricanes and Tropical Meteorology, San Diego, CA, Amer. Meteor. Soc., 206-207.

Franklin, J. L., S. J. Lord, S. E. Feuer, and F. D. Marks, 1993: The kinematic structure of Hurricane Gloria (1985) determined from nested analyses of dropwindsonde and Doppler wind data. Mon. Wea. Rev., 121, 2433-2451.

— , S. E. Feuer, J. Kaplan, and S. D. Aberson, 1996: Tropical cyclone motion and surrounding flow relationships: Searching for beta gyres in omega dropwindsonde datasets. Mon. Wea. Rev., 124, 64-84.

_ sonde wind profiles in hurricanes and their operational implications. Wea. Forecasting, 18, 32-44.

— C. J. McAdie, and M. B. Lawrence, 2003b: Trends in track forecasting for tropical cyclones threatening the United States, 1970-2001. Bull. Amer. Meteor. Soc., 84, 1197-1203.

Gamache, J. F., R. A. Houze Jr., and F. D. Marks Jr., 1993: Dual-aircraft investigation of the inner core of Hurricane Norbert. Part III: Water budget. J. Atmos. Sci., 50, 3221-3243.

Gayet, J. F., P. R. A. Brown, and F. Albers, 1993: A comparison of in-cloud measurements obtained from six PMS 2D-C probes. J. Atmos. Oceanic Technol., 10, 180-194.

Gentry, R. C., 1981: History of hurricane research in the United States with special emphasis on the National Hurricane Research Laboratory and associated groups. Preprints, 13th Technical Conf. on Hurricanes and Tropical Meteorology, Miami Beach, FL, Amer. Meteor. Soc., 6-16.

Govind, P. K., 1975: Dropwindsonde instrumentation for weather reconnaissance aircraft. J. Appl. Meteor., 14, 1512-1520.

Griffin, J. S., R. W. Burpee, F. D. Marks, and J. L. Franklin, 1992: Real-time airborne analysis of aircraft data supporting operational hurricane forecasting. Wea. Forecasting, 7, 480-490.

Hock, T. F., and J. L. Franklin, 1999: The NCAR GPS dropwindsonde. Bull. Amer. Meteor. Soc., 80, 407-420.

Houze, R. A., F. D. Marks Jr., and R. A. Black, 1992: Dual-aircraft investigation of the inner core of Hurricane Norbert. Part II: Mesoscale distribution of ice particles. J. Atmos. Sci., 49, 943-963.

_, F. D. Marks Jr., and R. A. Black, 2006: The Hurricane Rainband and Intensity Experiment (RAINEX): Observations and Modeling Hurricanes Katrina, Ophelia, and Rita (2005). Bull. Amer. Meteor. Soc., in press.

Jelesnianski, C. P., J. Chen, and W. A. Shaffer, 1992: SLOSH: Sea, lake and overland surges from hurricanes. NOAA Tech. Rep. NWS 48, Silver Spring, MD, $71 \mathrm{pp}$.

Jorgensen, D. P., 1984a: Mesoscale and convective-scale characteristics of mature hurricanes. Part I: General observations by research aircraft. J. Atmos. Sci., 41, 1267-1285.

_ 1984b: Mesoscale and convective-scale characteristics of mature hurricanes. Part II: Inner core structure of Hurricane Allen (1980). J. Atmos. Sci., 41, 1287-1311.

— , and P. T. Willis, 1982: A Z-R relationship for hurricanes. J. Appl. Meteor., 21, 356-366.

— P. H. Hildebrand, and C. L. Frush, 1983: Feasibility test of an airborne pulse-Doppler meteorological radar. J. Climate Appl. Meteor., 22, 744-757.

—, E. J. Zipser, and M. A. LeMone, 1985: Vertical motions in intense hurricanes. J. Atmos. Sci., 42, 839-856.

Kakar, R., M. Goodman, R. Hood, and A. Guillory, 2006: Overview of the Convection and Moisture Experiment (CAMEX). J. Atmos. Sci., 63, 5-18.

Kossin, J. P., and M. D. Eastin, 2001: Two distinct regimes in the kinematic and thermodynamic structure of the hurricane eye and eyewall. J. Atmos. Sci., 58, 1079-1090. 
Landsea, C. W., and Coauthors, 2004a: A reanalysis of Hurricane Andrew's (1992) intensity. Bull. Amer. Meteor. Soc., 85, 1699-1712.

- - and Coauthors, 2004b: The Atlantic hurricane database re-analysis project: Documentation for the 1851-1910 alterations and additions to the HURDAT database. Hurricanes and Typhoons: Past, Present and Future, R. J. Murnane and K.-B. Liu, Eds., Columbia University Press, 177-271.

Langland, R., 2005: Observation impact during the North Atlantic TReC-2003. Mon. Wea. Rev., 133, 2297-2309.

Lee, W.-C., F. D. Marks Jr., and R. E. Carbone, 1994: Velocity track display-A technique to extract real-time tropical cyclone circulations using a single airborne Doppler radar. J. Atmos. Oceanic Technol., 11, 337-356.

Malmquist, D. L., and A. F. Michaels, 2000: Severe storms and the insurance industry. Storms, Vol. I, R. A. Pielke Jr., and R. A. Pielke Sr., Eds., Routledge Press, 54-69.

Marks, F. D., 1985: Evolution of the structure of precipitation in Hurricane Allen (1980). Mon. Wea. Rev., 113, 909-930.

— observations in Hurricane Debby. Bull. Amer. Meteor. Soc., 65, 569-582.

_- and R. A. Houze, 1987: Inner core structure of Hurricane Alicia from airborne Doppler radar observations. J. Atmos. Sci., 44, 1296-1317.

—, R. A. Houze Jr., and J. F. Gamache, 1992: Dualaircraft investigation of the inner core of Hurricane Norbert. Part I: Kinematic structure. J. Atmos. Sci., 49, 919-942.

McAdie, C. J., and M. B. Lawrence, 2000: Improvements to tropical cyclone track forecasting in the Atlantic basin, 1970-1998. Bull. Amer. Meteor. Soc., 81, 989-997.

Moller, J. D., and M. T. Montgomery, 1999: Vortex Rossby waves and hurricane intensification in a barotropic model. J. Atmos. Sci., 56, 1674-1687.

—, and — 2000: Tropical cyclone evolution via potential vorticity anomalies in a three-dimensional balance model. J. Atmos. Sci., 57, 3366-3387.

Montgomery, M. T., and R. Kallenbach, 1997: A theory for vortex Rossby-waves and its application to spiral bands and intensity changes in hurricanes. Quart. J. Roy. Meteor. Soc., 123, 435-465.

—, M. Bell, S. D. Aberson, and M. L. Black, 2006: Hurricane Isabel (2003): New insights into the Physics of intense storms. Part I: Mean vortex structure and maximum intensity estimation. Bull. Amer. Meteor. Soc., in press.

Persing, J., and M. T. Montgomery, 2003: Hurricane superintensity. J. Atmos. Sci., 60, 2349-2371.
Powell, M. D., 1980: Evaluations of diagnostic marine boundary layer models applied to hurricanes. Mon. Wea. Rev., 108, 757-766.

— 1990a: Boundary layer structure and dynamics in outer hurricane rainbands. Part I. Mesoscale rainfall and kinematic structure. Mon. Wea. Rev., 118, 891-917.

— 1990b: Boundary layer structure and dynamics in outer hurricane rainbands. Part II: Downdraft modification and mixed layer recovery. Mon. Wea. Rev., 118, 918-938.

— ricane reconnaissance flight-level measurements to winds measured by NOAA's oceanic platforms. J. Wind Eng. Ind. Aerodyn., 36, 381-392.

— landfall in South Florida. Part II: Surface wind fields and potential real-time applications. Wea. Forecasting, 11, 329-349.

—, P. P. Dodge, and M. L. Black, 1991: The landfall of Hurricane Hugo in the Carolinas: Surface wind distribution. Wea. Forecasting, 6, 379-399.

— S. H. Houston, and T. A. Reinhold, 1996: Hurricane Andrew's landfall in South Florida. Part I: Standardizing measurements for documentation of surface wind fields. Wea. Forecasting, 11, 304-328.

—, P. J. Vickery, and T. A. Reinhold, 2003: Reduced drag coefficient for high wind speeds in tropical cyclones. Nature, 422, 279-283.

Rappaport, E. N., 2000: Loss of life in the United States associated with recent Atlantic tropical cyclones. Bull. Amer. Meteor. Soc., 81, 2065-2073.

Reasor, P. D., M. T. Montgomery, F. D. Marks, and J. F. Gamache, 2000: Low-wavenumber structure and evolution of the hurricane inner core observed by airborne dual-Doppler radar. Mon. Wea. Rev., 128, 1653-1680.

Rogers, R. F., and Coauthors, 2006: The Intensity Forecasting Experiment (IFE): A NOAA multi-year field program for improving tropical cyclone intensity forecasts. Bull. Amer. Meteor. Soc., in press.

Roux, F., and F. D. Marks, 1996: Extended velocity track display (EVTD): An improved processing method for Doppler radar observations in tropical cyclones. J. Atmos. Oceanic Technol., 13, 875-899.

—, and N. Viltard, 1995: Structure and evolution of Hurricane Claudette on 7 September 1991 from airborne Doppler radar observations. Part I: Kinematics. Mon. Wea. Rev., 123, 2611-2639.

Samsury, C. E., and E. J. Zipser, 1995: Secondary wind maxima in hurricanes: Airflow and relationship to rainbands. Mon. Wea. Rev., 123, 3502-3517. 
Shapiro, L. J., and H. E. Willoughby, 1982: The response of balanced hurricanes to local sources of heat and momentum. J. Atmos. Sci., 39, 378-394.

—, and J. L. Franklin, 1995: Potential vorticity in Hurricane Gloria. Mon. Wea. Rev., 123, 1465-1475.

Shay, L. K., P. G. Black, A. J. Mariano, J. D. Hawkins, and R. L. Elsberry, 1992: Upper-ocean response to Hurricane Gilbert. J. Geophys. Res., 97, 20 227-20 248.

Simpson, R. H., 1952: Exploring the eye of Typhoon "Marge," 1951. Bull. Amer. Meteor. Soc., 33, $286-$ 298.

_-, 1954: Hurricanes. Scientific American, 109, 22-37.

_, 1981: Implementation phase of the National Hurricane Research Project 1955-1956. Preprints, 13th Technical Conf. on Hurricanes and Tropical Meteorology, Miami Beach, FL, Amer. Meteor. Soc., 1-5.

—, 2001: The Hurricane and Its Impact. Louisiana State University Press, 398 pp.

—, Ed., 2003: Hurricanes! Coping with Disaster. Amer. Geophys. Union, 360 pp.

— Louisiana State University Press, 398 pp.

Sumner, H. C., 1943: North Atlantic hurricanes and tropical disturbances of 1943. Mon. Wea. Rev., 71, 179-183.

Szunyogh, I., Z. Toth, R. E. Morss, S. J. Majumdar, B. J. Etherton, and C. H. Bishop, 2000: The effect of targeted dropwonde observations during the 1999 Winter Storm Reconnaissance program. Mon. Wea. Rev., 128, 3520-3537.

— Z. Z. Toth, A. V. Zimin, S. J. Majumdar, and P. Persson, 2002: Propagation of the effect of targeted observations: The 2000 Winter Storm Reconnaissance program. Mon. Wea. Rev., 130, 1144-1165.

Uhlhorn, E. W., and P. G. Black, 2003: Verification of remotely sensed sea surface winds in hurricanes. $J$. Atmos. Oceanic Technol., 20, 99-116.

Viltard, N., and F. Roux, 1998: Structure and evolution of Hurricane Claudette on 7 September 1991 from airborne Doppler radar observations. Part II: Thermodynamics. Mon. Wea. Rev., 126, 281-302.

Webster, P. J., and R. A. Houze, 1991: The Equatorial Mesoscale Experiment (EMEX): An overview. Bull. Amer. Meteor. Soc., 72, 1481-1505.

— , and R. Lukas, 1992: TOGA COARE: The Coupled Ocean-Atmosphere Response Experiment. Bull. Amer. Meteor. Soc., 73, 1377-1415.
Wexler, H., 1945: The structure of the September, 1944, hurricane when off Cape Henry, Virginia. Bull. Amer. Meteor. Soc., 26, 156-159.

Whitehead, J. C., 2003: One million dollars per mile? The opportunity costs of hurricane evacuation. Ocean Coastal Manag., 46, 1069-1083.

Willoughby, H. E., 1990a: Temporal changes in the primary circulation in tropical cyclones. J. Atmos. Sci., 47, 242-264.

— 1990b: Gradient balance in tropical cyclones. J. Atmos. Sci., 47, 265-274.

- 1998: Tropical cyclone eye thermodynamics. Mon. Wea. Rev., 126, 3053-3067.

— , and M. B. Chelmow, 1982: Objective determination of hurricane tracks from aircraft observations. Mon. Wea. Rev., 110, 1298-1305.

_- and M. E. Rahn, 2004: Parametric representation of the primary hurricane vortex. Part I: Observations and evaluation of the Holland (1980) model. Mon. Wea. Rev., 132, 3033-3048.

— J. J. Clos, and M. G. Shoreibah, 1982: Concentric eye walls, secondary wind maxima, and the evolution of the hurricane vortex. J. Atmos. Sci., 39, 395-411.

_-, F. D. Marks, and R. J. Feinberg, 1984: Stationary and moving convective bands in hurricanes. J. Atmos. Sci., 41, 3189-3211.

— D. P. Jorsensen, R. A. Black, and S. L. Rosenthal, 1985: Project STORMFURY: A scientific chronicle 1962-1983. Bull. Amer. Meteor. Soc., 66, 505-514.

_, R. W. R. Darling, and M. E. Rahn, 2006: Parametric representation of the primary hurricane vortex. Part II: A new family of sectionally continuous profiles. Mon. Wea. Rev., 134, 1102-1120.

Wood, F. B., 1945: A flight into the September, 1944, hurricane off Cape Henry, Virginia. Bull. Amer. Meteor. Soc., 26, 153-156.

Wroe, D. R., and G. M. Barnes, 2003: Inflow layer energetics of Hurricane Bonnie (1998) near landfall. Mon. Wea. Rev., 131, 1600-1612.

Wu, C.-C., and Coauthors, 2005: Dropwindsonde observations for typhoon surveillance near the Taiwan region (DOTSTAR): An overview. Bull. Amer. Meteor. Soc., 86, 787-790.

Yuter, S. E., R. A. Houze, B. F. Smull, F. D. Marks, J. R. Daugherty, and S. R. Brodzik, 1995: TOGA COARE aircraft mission summary images: An electronic atlas. Bull. Amer. Meteor. Soc., 76, 319-328. 